\title{
Key mortality causes of the Great Bustard (Otis tarda) in Central Hungary: an analysis of known fatalities
}

\author{
CsABA VAdÁsz \& Miklós LóRÁNT
}

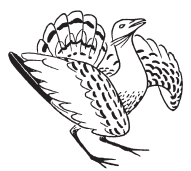

Csaba Vadász \& Miklós Lóránt 2014. Key mortality causes of the Great Bustard (Otis tarda) in Central Hungary: an analysis of known fatalities. - Ornis Hungarica 22(2): 32-41.

data collection that have been (Otied tarda) and quantified the relative in gion in Central Hungary been carried out during the period between 2005 and 2014 at the Upper-Kiskunsag refactors. Within the anthropogenic factors leading to mortality, collision was represented by $81.48 \%$ of fatalities, whereas mowing/hay making represented by $18.52 \%$. Hay making/mowing was the factor leading to unsuccessful breeding attempt with the strongest negative effect on the breeding success of the investigated population of the Great Bustard, as it was represented by $50.96 \%$ of all known mortality cases. Chemical treatment had the factor with the second strongest effect, as it was represented by $12.33 \%$ of all known mortality cases. The rate of unsuccessful breeding (hatching) caused by particular activities (hay making/mowing, tillage, harvesting) varied between $68.42 \%$ and $75.00 \%$. It was the disturbance by passers-by which led to the highest portion of unsuccessful breeding with $83.33 \%$ unsuccessful nests.

Keywords: Great Bustard, mortality factors, collision with cables, mowing, anthropogenic disturbance

Összefoglalás Munkánkban a túzok (Otis tarda) tojásai elpusztulásának, illetve a juvenilis és adult korú egyedek elhullásának okait vizsgáltuk a Felső-Kiskunságban a 2005-2014 közötti időszakban. A juvenilis és adult korú egyedek elhullásának oka 39,71\%-ban volt emberi hatásokra visszavezethető, ezeken belül is a légvezetékekkel való ütközés reprezentálta messze a legtöbb elhullást $(81,48 \%)$. A kaszálás, mint mortalitási faktor jellemzően a pullus korú egyedek pusztulásához vezetett (18,52\%). A tojások kikelésének sikertelenségéhez a kaszálás járult hozzá legnagyobb mértékben (az összes sikertelen kelés 50,96\%-a erre volt visszavezethető). A szántóföldi kultúrák vegyszeres növényvédelme 12,33\%-át tette ki a sikertelen kelések okainak. A különböző típusú zavarások (mezőgazdasági munkák) után a kelés sikertelensége 68,42-75,00\% között változott. A gyalogos közlekedés során felriasztott tojók fészkeinek $83,33 \%$-ánban volt sikertelen a kelés.

Kulcsszavak: túzok, elhullási okok, légvezetékkel való ütközés, kaszálás, antropogén zavarás

Kiskunság National Park Directorate, 6000 Kecskemét, Liszt Ferenc utca 19., Hungary, e-mail: vadaszcs@knp.hu *correspondig author

\section{Introduction}

Although it is usually impossible to follow the life history of every single individual of a wild population, it would evidently be of great importance to be able to estimate the relative importance of different factors which lead to death of individuals. From nature conservation perspective, by identifying those threatening factors that can be neutralized (or minimized, at least), vulnerable populations could be enforced as habitat management could be based on real data, which would form the basis of evidence-based conservation (see Sutherland et al. 2004). In financial perspective, available 
resources can be allocated optimally (i.e. it would provide us with the possibility to finance those interventions which would contribute to stabilizing a certain population at lowest costs.

The Great Bustard is a relatively well known bird species (Alonso et al. 1994) via its vulnerable status (BirdLife International 2013). However, there is still poor information about the quantitative life table for its Hungarian populations. Nevertheless, by gathering information from different resources, it is possible to construct a model describing the age-specific mortality. For conservationists, these kind of models can provide important management implications. Furthermore, the recently unquantifiable units/parts of these models can assign potential topics for future scientific research.

In this study, by summing all the available information about the most numerous Great Bustard population in Hungary (see Práger 2005, Alonso \& Palacín 2010), we identified the key mortality causes and quantified the relative importance of those, based on systematic data collection that have been carried out during the period between 2005 and 2014.

\section{Materials and methods}

\section{The study area and the investigated population}

The study area is located at the UpperKiskunság region in Central Hungary. This area is characterized by large-scale mosaics of unwooded grasslands and ploughfields, hosting the largest Pannonian Great Bustard population, which, in fact still shows continuous increase (Práger 2005). Major part of the area is designated as a Special Protection Area in the Natura 2000 network (HUKN10001 and HUKN10002). The core area of the Great Bustard population (including the displaying and the nesting sites) falls under national protection, forming parts of Kiskunság National Park.

\section{Datasets used}

Known fatalities regarding juveniles, immatures and adults

The factor leading to the death of every single individual was determined by investigating all the carcasses found during the systematic monitoring and irregular activities (e.g. notification from farmers, land owners, etc. about dead Great Bustards) between 2005 and 2014.

\section{Known fatalities regarding eggs}

Between 2005 and 2014, all the cases regarding unsuccessful attempts on hatching eggs having been laid in nests found accidently during different kind of field works and other activities (e.g. hunting) were categorized based on the type of the field work/ activity.

\section{Threatening factors of the nests}

Between 2005 and 2014, the fate of all the eggs having been laid in nests found accidently during different kind of field works and other activities (e.g. hunting) was investigated. There were no efforts put into finding nests except for the ones having been revealed by the above mentioned activities.

\section{The number of revealed nests in the case of lands with different legal/protection status}

The location of each nesting site was classified based on the combination of type of 
utilization and protection status of the land hosting the nest. Regarding the type of utilization, three categories were set: (1) arable fields, (2) mowed meadows, (3) pastures. Regarding the protection status, four categories were set: (1) no protection with intensive utilization, (2) no protection with no utilization, (3) involvement in the agri-environmental scheme focusing on the protection of the Great Bustard, (4) regulated (restricted) by nature conservation authorities (at land falling under protection at national level). Thus, each site was assigned to one of the twelve combinations of the above mentioned categories. Due to prior experience, the probability of detection of the presence of a breeding female in the case of the particular land type is shown in Table 1. This probability value reflects the assumption that a female taking wings is surely observed by the person performing the disturbing activity. Accordingly, this value can be regarded as an indicator of intensity of the particular form of land use. Since the legal regulations on agri-environmental scheme focusing on the protection of the Great Bustard were different in the case of the two periods (i.e. the one between 2005 and 2009, and the other between 2009 and 2014), the set of field works allowed to be carried out was different, evidently resulting in different values of probability of detection of a certain nest. Accordingly, in this analysis nest having been revealed during exclusively the second programme (between 2009 and 2014) were included.

\section{Results}

\section{Mortality causes of juvenile, immature and adult individuals}

Between 2005 and 2014, 68 fatalities have been recorded regarding juvenile and adult individuals. The list of mortality causes are shown in Table 2. The portion of fatalities caused by: natural factors (including predation and diseases) is $58.82 \%$, anthropogenic factors is $39.71 \%$ and unknown factors is $1.47 \%$. Collision with different kind of cables (medium voltage power lines, railway cables, electric fences) was represented by $32.35 \%$ of all known fatalities. Within the anthropogenic factors leading to mortality, collision was represented by $81.48 \%$ of fatalities, whereas mowing/hay making represented by $18.52 \%$.

\section{Mortality causes of eggs}

Between 2005 and 2014, 209.2 fatalities have been recorded regarding eggs (In the case of destroyed nests, when it was not possible to determine the clutch size (i.e. the number of eggs), the number of destroyed eggs was calculated as 1.8/nest). The list of mortality causes are listed in Table 3. Hay making/mowing was the factor leading to unsuccessful breeding attempt with the strongest negative effect on the breeding success of the investigated population of the Great Bustard, as it was represented by $50.96 \%$ of all known mortality cases. Chemical treatment was the factor with the second strongest effect, as it was represented by $12.33 \%$ of all known mortality cases.

\section{Threatening factors of nest}

Between 2005 and 2014, 199 nests have been revealed during different kind of field activities or works. The portion of nests characterized with unsuccessful and successful hatching in the case of specific activities that led to detection of the nests is shown in Table 4. 


\begin{tabular}{|c|c|c|c|c|}
\hline & $\begin{array}{l}\text { No protection, } \\
\text { intensive utilization }\end{array}$ & $\begin{array}{l}\text { No protection, } \\
\text { no utilization }\end{array}$ & $\begin{array}{l}\text { Agri-environmental } \\
\text { scheme focusing on } \\
\text { the protection of the } \\
\text { Great Bustard }\end{array}$ & $\begin{array}{l}\text { Regulated (restricted) } \\
\text { by nature conservation } \\
\text { authorities (at land fall- } \\
\text { ing under protection at } \\
\text { national level) }\end{array}$ \\
\hline $\begin{array}{l}\text { Arable } \\
\text { fields }\end{array}$ & $\begin{array}{l}\text { Any type of field } \\
\text { works is likely to be } \\
\text { carried out at least } \\
\text { once during the in- } \\
\text { cubation period, thus } \\
\text { the probability of de- } \\
\text { tection of a breeding } \\
\text { female (i.e. the nest) is } \\
\text { approx. } 100 \% \text {. }\end{array}$ & $\begin{array}{l}\text { No field work } \\
\text { is likely to be } \\
\text { carried out, thus } \\
\text { the probability } \\
\text { of detection of a } \\
\text { breeding female } \\
\text { (i.e. the nest) is } \\
\text { approx. } 0 \% \text {. }\end{array}$ & $\begin{array}{l}\text { Due to the regulations } \\
\text { of the agri-environmen- } \\
\text { tal scheme the proba- } \\
\text { bility of detection of a } \\
\text { breeding female (i.e. the } \\
\text { nest) is approx. } 60 \% \text {. }\end{array}$ & $\begin{array}{l}\text { No field work is likely to } \\
\text { be carried out, thus the } \\
\text { probability of detection } \\
\text { of a breeding female (i.e. } \\
\text { the nest) is approx. } 0 \% \text {. }\end{array}$ \\
\hline $\begin{array}{l}\text { Mowed } \\
\text { meadows }\end{array}$ & $\begin{array}{l}\text { Mowing is likely to } \\
\text { be carried out at least } \\
\text { once during the incu- } \\
\text { bation period, thus } \\
\text { the probability of de- } \\
\text { tection of a breeding } \\
\text { female (i.e. the nest) } \\
\text { is approx. } 100 \% \text {. }\end{array}$ & $\begin{array}{l}\text { No mowing } \\
\text { is likely to be } \\
\text { carried out, thus } \\
\text { the probability } \\
\text { of detection of a } \\
\text { breeding female } \\
\text { (i.e. the nest) is } \\
\text { approx. } 0 \% \text {. }\end{array}$ & $\begin{array}{l}\text { No mowing is likely to } \\
\text { be carried out during } \\
\text { the incubation period, } \\
\text { thus the probability of } \\
\text { detection of a breeding } \\
\text { female (i.e. the nest) is } \\
\text { approx. } 0 \% \text {. }\end{array}$ & $\begin{array}{l}\text { No mowing is likely to } \\
\text { be carried out during } \\
\text { the incubation period, } \\
\text { thus the probability of } \\
\text { detection of a breeding } \\
\text { female (i.e. the nest) is } \\
\text { approx. } 0 \% \text {. }\end{array}$ \\
\hline Pastures & $\begin{array}{l}\text { Since the presence } \\
\text { of a herder/farmer } \\
\text { is influenced by the } \\
\text { grazing system (e.g. } \\
\text { electric fence with } \\
\text { no herder, traditional } \\
\text { pasturing etc.), the } \\
\text { probability of detec- } \\
\text { tion of a breeding } \\
\text { female (i.e. the nest) } \\
\text { is indefinable. }\end{array}$ & $\begin{array}{l}\text { No grazing } \\
\text { is likely to be } \\
\text { carried out, thus } \\
\text { the probability } \\
\text { of detection of a } \\
\text { breeding female } \\
\text { (i.e. the nest) is } \\
\text { approx. } 0 \% \text {. }\end{array}$ & $\begin{array}{l}\text { Since the presence of a } \\
\text { herder/farmer is influ- } \\
\text { enced by the grazing } \\
\text { system (e.g. electric } \\
\text { fence with no herder, } \\
\text { traditional pasturing } \\
\text { etc.), the probability of } \\
\text { detection of a breeding } \\
\text { female (i.e. the nest) is } \\
\text { indefinable. }\end{array}$ & $\begin{array}{l}\text { Since the presence of a } \\
\text { herder/farmer is influ- } \\
\text { enced by the grazing } \\
\text { system (e.g. electric } \\
\text { fence with no herder, } \\
\text { traditional pasturing } \\
\text { etc.), the probability of } \\
\text { detection of a breeding } \\
\text { female (i.e. the nest) is } \\
\text { indefinable. }\end{array}$ \\
\hline
\end{tabular}

Table 1. The probability of detection a certain breeding female Great Bustard (i.e. a certain nest) in the case of lands with different type of utilization and protection status based on prior experience

1. táblázat Egy, az adott típusú hasznosítás alatt álló, illetve védettségi szintű területen költő túzok tojó észlelésének (fészek megtalálásának) valószínűsége 


\begin{tabular}{|l|c|}
\hline \multicolumn{1}{|c|}{ Mortality causes } & Number of detected dead individuals \\
\hline Natural (excluding predation and diseases) & 37 \\
\hline Collision with medium voltage power lines & 14 \\
\hline Collision with railway cables & 7 \\
\hline Hey making/mowing & 5 \\
\hline Diseases & 2 \\
\hline Collision with electric fence & 1 \\
\hline Predation & 1 \\
\hline Unknown & 1 \\
\hline Total & 68 \\
\hline
\end{tabular}

Table 2. Mortality causes of juvenile and adult Great Bustards in Central Hungary between 2005 and 2014 based on known fatalities

2. táblázat A juvenilis és adult túzokok elhullásának okai a Duna-Tisza közi populáció esetében, a 2005 és 2014 között detektált esetekben

\begin{tabular}{|l|c|}
\hline \multicolumn{1}{|c|}{ Mortality causes } & $\begin{array}{c}\text { Number of eggs (regarding un- } \\
\text { successful breeding attempts) }\end{array}$ \\
\hline Hey making/mowing & 106.6 \\
\hline Chemical treatment of crops & 25.8 \\
\hline Tillage & 18.8 \\
\hline Unknown & 14.2 \\
\hline Harvesting & 11.8 \\
\hline Grazing by livestock & 8 \\
\hline Eggs left by females due to human disturbance (passersby) & 7 \\
\hline Secondary tillage (with cultivators) & 5 \\
\hline Eggs left by females due to human disturbance (cars) & 3 \\
\hline Sowing & 2 \\
\hline Predation & 2 \\
\hline Silage making & 2 \\
\hline Soil preparation & 2 \\
\hline Eggs left by females due to hunting & 1 \\
\hline Total & 209.2 \\
\hline
\end{tabular}

Table 3. Mortality causes of Great Bustard eggs in Central Hungary between 2005 and 2014 based on known fatalities. In the case of destroyed nests, when the number of eggs could not been possible to determine, the number of destroyed eggs was calculated as 1.8

3. táblázat A túzok tojások pusztulásának okai a Duna-Tisza közi populáció esetében, a 2005 és 2014 között detektált esetekben. Azokban az esetekben, amikor a fészekalj pusztulásakor a tojásszám nem volt meghatározható, az elpusztult tojások számát 1,8-nek becsültük 


\begin{tabular}{|c|c|c|c|c|}
\hline $\begin{array}{l}\text { Threatening } \\
\text { factors }\end{array}$ & $\begin{array}{l}\text { Number of } \\
\text { revealed } \\
\text { nests due to } \\
\text { the specific } \\
\text { activity }\end{array}$ & $\begin{array}{l}\text { Portion of unsuccessful } \\
\text { breeding attempts } \\
\text { within all detected nests } \\
\text { (and within the nests } \\
\text { with known fate) }\end{array}$ & $\begin{array}{l}\text { Portion of successful } \\
\text { breeding attempts } \\
\text { within all detected } \\
\text { nests (and within the } \\
\text { nests with known fate) }\end{array}$ & $\begin{array}{l}\text { Portion of } \\
\text { breeding } \\
\text { attempts with } \\
\text { unknown } \\
\text { success }\end{array}$ \\
\hline $\begin{array}{l}\text { Hay making/ } \\
\text { mowing (alfalfa } \\
\text { fields) }\end{array}$ & 62 & $\begin{array}{c}62.90 \% \\
(68.42 \%)\end{array}$ & $\begin{array}{c}29.03 \% \\
(31.58 \%)\end{array}$ & $8.06 \%$ \\
\hline $\begin{array}{l}\text { Hay making/ } \\
\text { mowing } \\
\text { (grasslands) }\end{array}$ & 28 & $\begin{array}{l}75.00 \% \\
(75.00 \%)\end{array}$ & $\begin{array}{l}25.00 \% \\
(25.00 \%)\end{array}$ & $0.00 \%$ \\
\hline $\begin{array}{l}\text { Chemical } \\
\text { treatment of } \\
\text { crops }\end{array}$ & 40 & $\begin{array}{c}35.00 \% \\
(43.75 \%)\end{array}$ & $\begin{array}{c}45.00 \% \\
(56.25 \%)\end{array}$ & $20.00 \%$ \\
\hline Tillage & 16 & $\begin{array}{l}56.25 \% \\
(75.00 \%)\end{array}$ & $\begin{array}{c}18.75 \% \\
(25.00 \%)\end{array}$ & $25.00 \%$ \\
\hline Unknown & 13 & $\begin{array}{c}76.92 \% \\
(83.33 \%) \\
\end{array}$ & $\begin{array}{c}15.38 \% \\
(16.67 \%) \\
\end{array}$ & $7.69 \%$ \\
\hline Harvesting & 9 & $\begin{array}{l}66.67 \% \\
(75.00 \%)\end{array}$ & $\begin{array}{l}22.22 \% \\
(25.00 \%)\end{array}$ & $11.11 \%$ \\
\hline $\begin{array}{l}\text { Grazing by } \\
\text { livestock }\end{array}$ & 9 & $\begin{array}{c}44.44 \% \\
(57.14 \%)\end{array}$ & $\begin{array}{l}33.33 \% \\
42.86 \%)\end{array}$ & $22.22 \%$ \\
\hline $\begin{array}{l}\text { Eggs left by } \\
\text { females due } \\
\text { to human } \\
\text { disturbance } \\
\text { (passersby) }\end{array}$ & 9 & $\begin{array}{l}55.56 \% \\
(83.33 \%)\end{array}$ & $\begin{array}{c}11.11 \% \\
(16.67 \%)\end{array}$ & $33.33 \%$ \\
\hline $\begin{array}{l}\text { Secondary tillage } \\
\text { (with cultivators) }\end{array}$ & 4 & $\begin{array}{l}75.00 \% \\
(75.00 \%)\end{array}$ & $\begin{array}{l}25.00 \% \\
(25.00 \%)\end{array}$ & $0.00 \%$ \\
\hline $\begin{array}{l}\text { Eggs left by } \\
\text { females due } \\
\text { to human } \\
\text { disturbance (cars) }\end{array}$ & 2 & $100.00 \%$ & $0.00 \%$ & $0.00 \%$ \\
\hline Sowing & 1 & $100.00 \%$ & $0.00 \%$ & $0.00 \%$ \\
\hline Silage making & 1 & $100.00 \%$ & $0.00 \%$ & $0.00 \%$ \\
\hline Soil preparation & 1 & $100.00 \%$ & $0.00 \%$ & $0.00 \%$ \\
\hline $\begin{array}{l}\text { Eggs left by } \\
\text { females due to } \\
\text { hunting }\end{array}$ & 3 & $33.33 \%$ & $0.00 \%$ & $66.67 \%$ \\
\hline Stalk chopping & 1 & $0.00 \%$ & $0.00 \%$ & $100.00 \%$ \\
\hline
\end{tabular}

Table 4. Threatening factors of Great Bustard nests in Central Hungary between 2005 and 2014 based on data originating from discovered nests

4. táblázat A túzok fészkeket veszélyeztető tényezők a Duna-Tisza közi populáció esetében, a 2005 és 2014 között detektált esetekben, a megtalált fészkek alapján 
Hay making/mowing (regarding both alfalfa fields and grasslands) led to the detection of $45.22 \%$ of all revealed nests, whereas chemical treatment of crops led to $20.10 \%$ of all revealed nests, all the soil tilling (including soil preparation, tillage, secondary tillage) led to $10.55 \%$ of all revealed nests, grazing led to $4.52 \%$ of all revealed nests and unintended disturbance (by passersby, cars, hunters) led to $6.30 \%$ of all revealed nests.

There were 11 specific activities that led to detection of more than one nest. Regarding these activities, the portion of unsuccessful breeding attempts ranged between $43.75 \%$ and $83.33 \%$. It was chemical treatment of crops which represented the lowest negative impact on hatching probability, as $56.25 \%$ of nests with known fate were successful. Most activities (hay making/mowing, tillage, harvesting) led to unsuccessful breeding attempt (hatching) in roughly $75 \%$ $(68.42 \%$ to $75.00 \%)$ of specific cases with known fate. It was the disturbance by passersby that led to the highest portion of unsuccessful breeding (hatching) with $83.33 \%$ unsuccessful nests.

\section{Number of revealed nests in the case of lands with different type of utilization and protection status}

Between 2009 and 2014, 91 nests have been revealed. The number of revealed nests assigned to the specific categories is shown in Table 5.

Most of the nests were found at plough fields $(73.26 \%$ ), at grasslands $20.88 \%$ (mowed meadows) and $2.20 \%$ (pastures) of the nests were detected.

Regarding the intensity of cultivation, $59.34 \%$ of all nests were detected at intensively cultivated lands (with no restrictions),
$32.97 \%$ at lands covered by the agri-environmental scheme focusing on the protection of the Great Bustard and $7.69 \%$ at areas protected at national level.

\section{Discussion}

The Great Bustard is represented with a globally vulnerable population (BirdLife International 2013) with low average breeding success which shows expressed annual variance (Morales et al. 2002). Threatening factors influencing the survival of individuals belonging to particular population have been quantitatively assessed (see Alonso et al. 1994). Hungary hosts approximately $3 \%$ of the world population, as the Great Bustard population inhabiting the Carpathian Basin is the second largest in Europe (Alonso \& Palacín 2010). Recently the largest and still growing Hungarian population of the Great Bustard is the one in Upper-Kiskunság at Central Hungary. In this study, based on known fatalities, we analysed the relative importance of different killing factors.

Regarding juvenile, immature and adult individuals, anthropogenic factors represent approximately $40 \%$ of all mortality causes in the case of the investigated population of the Great Bustard. Amongst these, collision with cables (especially medium voltage power lines and railway cables) is the mortality factor with far the strongest negative effect. Taking into consideration the fact that large part of birds cannot be found and thus are omitted from the reports (Ponce et al. 2010), the killing effect of cables must be even stronger. Although there are some solutions for reducing the risk of collision, such as the application of flight diverters on wires (Alonso et al. 1994), undergrounding of power lines would be the ultimate solu- 


\begin{tabular}{|l|c|c|c|c|c|}
\hline & $\begin{array}{c}\text { No protec- } \\
\text { tion, inten- } \\
\text { sive utiliza- } \\
\text { tion }\end{array}$ & $\begin{array}{c}\text { No protec- } \\
\text { tion, no } \\
\text { utilization } \\
\text { (abandoned } \\
\text { lands) }\end{array}$ & $\begin{array}{c}\text { Agri-environmen- } \\
\text { tal scheme focus- } \\
\text { ing on the protec- } \\
\text { tion of the Great } \\
\text { Bustard }\end{array}$ & $\begin{array}{c}\text { Regulated (restric- } \\
\text { ted) by nature con- } \\
\text { servation authori- } \\
\text { ties (at land falling } \\
\text { under protection at } \\
\text { national level) }\end{array}$ & Total \\
\hline Arable fields & 44 & 0 & 22 & 1 & $\mathbf{6 7}$ \\
\hline Mowed meadows & 9 & 0 & 6 & 4 & $\mathbf{1 9}$ \\
\hline Pastures & 1 & 0 & 2 & 2 & $\mathbf{5}$ \\
\hline Total & $\mathbf{5 4}$ & $\mathbf{0}$ & $\mathbf{3 0}$ & $\mathbf{7}$ & 91 \\
\hline
\end{tabular}

Table 5. Number of revealed nests in the case of lands with different type of utilization and protection status in Central Hungary between 2005 and 2014 based on data originating from discovered nests

5. táblázat Az adott típusú hasznosítás alatt álló, illetve védettségi szintű területeken detektált túzok fészkek száma a Duna-Tisza közi populáció esetében, a 2005 és 2014 közötti időszakban

tion (Raab et al. 2011, Raab et al. 2012, Lóránt \& Vadász 2014).

In the case of railway cables, the only solution for reducing the risk of collision could be the use of markings increasing the detectability of cables by the Great Bustards, and also the sustenance/establishment of alley of trees along railways. Of course, it should be considered that dense afforestations could result in fragmentation of Great Bustard habitats.

Regarding hay making/mowing, birdfriendly mowing methods and the prior announcement of mowing towards the nature conservation manager by the land user in the case of every potential Great Bustard breeding site could be the solution for reducing the number of destroyed nests and killed pulli and juveniles. Recently, mowing carried out at grasslands located in protected and/or NATURA 2000 areas must be announced in advance towards the nature conservation manager (i.e. National Park Directorates).

Even predation is usually reported as one of the major killing factors in the case of the Great Bustard and other ground-nesting avian species (Langgemach \& Belle- baum 2005), our dataset includes only a few records on fatalities caused by predators. The density of potential predators, such as the Hooded Crow (Corvus corone), the Red Fox (Vulpes vulpes), the European Badger (Meles meles) and Wild Boar (Sus scrofa) is rather high at the breeding grounds of the Great Bustard in the Upper-Kiskunság region, but with the recent monitoring techniques the probability of detection of predation equals roughly with zero. Carcasses found at warrens of mammal predators cannot be regarded as unambiguous evidence for predation, since these predators can bring carrion (i.e. Great Bustards found dead) to their warrens. Specific future investigations (e.g. analysis of droppings and/or bromatological investigations) could reveal the relative impact of potential predators on the Great Bustard populations. For same reasons, in the case of eggs having been permanently left by the females after having faced a certain kind of human disturbance, even the left eggs can be consumed by Hooded Craws, it is not nest predation which de facto led to egg mortality.

Chemical treatments of cereals seems to affect nesting success far less, than the other 
kind of field works, as the portion of abandoned nests is approximately half as high as it use to be in the case of other kind of disturbances, such as mowing, tillage etc. Nevertheless, the successive field works (e.g. harvesting) and the reduced amount of food (insects) after chemical treatment may further decrease the breeding success (Ponce $e t$ al. 2011).

Regarding the unintended disturbances (i.e. those cases, when a breeding female is frightened off the nest and it abandons the $\operatorname{egg}(\mathrm{s})$ facing an activity which is not related agriculture, e.g. due to the approach of passerby, see Sastre et al. 2009), the portion of unsuccessful breeding attempts is quite high. As these activities are not obligatory to be carried out (from agricultural perspective), with the modification of legal regulation (e.g. in the case of regulation of hunting at the breeding areas) and awareness raising focusing the rural communities and especially the farmers would significantly reduce the overall negative effects of unintended disturbances.

In addition, the influence of specific activities decreasing level of successful breeding attempts must be considered as an apparent value. In the case of infertile eggs, sooner or later the nest is left by the females, but apparently the eggs are abandoned due to some kind of human disturbance. In the case of eggs removed from endangered nests and transferred to the Great Bustard Protection Centre in Dévaványa (i.e. from those nests where there was no chance for the survival of eggs, e.g. in the case of those with too small buffer zone left uncut, etc.) fertility of eggs was investigated, and the portion of infertile and unviable eggs appeared to be surprisingly high, approximately $40 \%$ (unpublished data).

Regarding the natural threatening factors that have negative effect on the breeding success of the Great Bustard, it should be considered that a population of a longliving species can sustain with low level of breeding success, since the high rate of annual survival in the case of the successive stages can compensate it so that inner reproductive rate remains positive (or zero, at least). However, even relatively low level of mortality induced by anthropogenic killing factors (in relation to the level of mortality caused by natural killing effects) can decrease the inner reproductive rate, so that it can become negative, resulting in decrease in population size. Accordingly, the most important task is to eliminate (or reduce, at least) the killing effect of anthropogenic factors by the adequate concrete conservation measure (like underground cabling), modification of legal regulations and by the implementation of field works compatible with the sustenance of the Great Bustard. 


\section{References}

Alonso, J. C., Alonso, J. A. \& Muñoz-Pulido, R. 1994. Mitigation of bird collisions with transmission lines through groundwire marking. Biological Conservation 67(2): 129-134. DOI: 10.1016/0006-3207(94)90358-1

Alonso, J. C. \& Palacín, C. 2010. The world status and population trends of the Great Bustard: 2010 update. - Chinese Birds 1: 141-147. DOI: 10.5122/ cbirds.2010.0007

BirdLife International 2013. Otis tarda. - The IUCN Red List of Threatened Species. Version 2014.3.

Langgemach, T. \& Bellebaum, J. 2005. Predation and the conservation of ground-breeding birds in Germany. - Vogelwelt 126: 259-298.

Lóránt, M. \& Vadász, Cs. 2014. The effect of aboveground medium voltage power lines on displaying site selection of the Great Bustard Otis tarda in Central Hungary. - Ornis Hungarica 22(2): 42-49.

Morales, M. B., Alonso, J. C. \& Alonso, J. A. 2002. Annual productivity and individual female reproductive success in a Great Bustard Otis tarda population. - Ibis 114: 293-300. DOI: 10.1046/j.1474-919X.2002.00042.x

Ponce, C., Alonso, J. C., Argandona, G., Garcia Fernandez, A. \& Carrasco, M. 2010. Carcass removal by scavengers and search accuracy affect bird mortality estimates at power lines. - Animal Conservation 13(6): 603-612. DOI: 10.1111/j.14691795.2010.00387.x
Ponce, C., Bravo, C., García De León, D., Magana, M. \& Alonso, J. C. 2011. Effects of organic farming on plant and arthropod communities: a case study in Mediterranean dryland cereal. - Agriculture, Ecosystems and Environment 141: 193-201. DOI: 10.1016/j.agee.2011.02.030

Raab, R., Schütz, C., Spakovszky, P., Julius, E. \& Schulze, C. H. 2012. Underground cabling and marking of power lines: conservation measures rapidly reduced mortality of West-Pannonian Great Bustards Otis tarda. - Bird Conservation International 22: 299-306. DOI: 10.1017/ S0959270911000463

Raab, R., Spakovszky, P., Julius, E., Schütz, C. \& Schulze, C. H. 2011. Effects of power lines on flight behaviour of the West-Pannonian Great Bustard Otis tarda population. - Bird Conservation International 21: 142-155. DOI: $10.1017 /$ S0959270910000432

Sastre, P., Ponce, C., Palacín, C., Martín, C. A. \& Alonso, J. C. 2009. Disturbances to Great Bustards (Otis tarda) in central Spain: human activities, bird responses and management implications. - European Journal of Wildlife Research 55: 425432. DOI: 10.1007/s10344-009-0254-7

Sutherland, W. J., Pullin, A. S., Dolman, P. M. \& Knight, T. M. 2004. The need for an evidence-based conservation. - Trends in Ecology and Evolution 19(6): 305-308. DOI: 10.1016/j. tree.2004.03.018

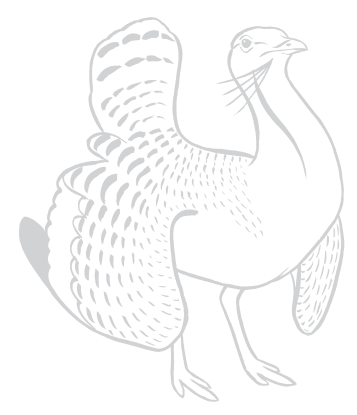

